\title{
Studies on contamination and quality of fresh fish meats during storage
}

\author{
Gamal El-Deen, M. R. El-Shamery \\ Dept of Micro, Fac of Science, Taiz Univ, Republic of Yemen \\ E-mail_:HYPERLINK "mailto:GAMALRASAM@YAHOO.COM " \\ GAMALRASAM@YAHOO.COM
}

\begin{abstract}
The aimed of this study showed the possibility to evaluate the quality and find out the degree of contamination of local fresh fish meats, this fish its common name in Yemen is (Gahsh), and its scientific name is (Lethrinus elongatus). The samples taken from Taiz city markets [Republic of Yemen], and stored at room temperature, the microbiological, physical and chemical changes were followed by examination of samples during storage at zero time as (control samples) and every day. The results illustrate the microbial contamination increasing and the evaluation of the physical and chemical characteristics quality were decreased and deteriorated during storage. As well as isolation seventeen species of bacteria identified and classification to six groups of Bacillus spp obtained from prior samples. On other hand the population of Aerobic, Anaerobic, Spore formers, Yeast and Moulds Enterobacteriaceae, Coli form groups, Salmonella spp, Staphylococcus spp, Streptococcus spp, Clostridium spp, Bacillus spp, Enterococcus spp and Proteolysis bacteria, were increased by the following percentages: $68.56 \%, 43.2 \%, 26.75 \%$, $28.82 \%, 49.59 \%, 16.66 \%, 15.00 \%, 30.53 \%, 24.24 \%, 16.92 \%, 14.52 \%, 14.49 \%$, and $50.50 \%$ respectively. The nutrition chemical characteristics i.e [Moisture, Protein and Fat content] were decreased as following percentages: $0.81 \%, 0.54 \%$ and $0.63 \%$ respectively, and the Carbohydrate content increasing as $43.97 \%$. The chemical indicates for spoilage i.e [Total volatile nitrogen, Tri methyl amine, Ammonia nitrogen, Thiobarabituric acid, Total energy value and Water holding capacity] increasing as following percentages: $147.87 \%, 114.74 \%, 82.55 \%, 62.57 \%, 1.43 \%$ and $16.36 \%$ respectively. The $\mathrm{pH}$ value and Bound water decreased as $7.00 \%$ and $3.89 \%$ respectively, as compared with the control samples.
\end{abstract}

Keywords: Microbial, fish, storage, quality, contamination.

\section{INTRODUCTION}

From the earliest civilization, all societies have had two means for ensuring adequate supplies of safe and nutritious food to meat the needs of their people (kaferstein and Moy 1999). The quality of fish meat is the reflection of microbiological,physical and chemical characteristics before and during storage (Abd El-Latife, 1998). Nutritional and protein play an important role in the life of man and nation, fish are known for their high nutritional quality they are relatively low in fat, saturated fat, and cholesterol, and high in polyunsaturated fatty acids, protein and minerals such as calcium, phosphorus, sodium, potassium and magnesium (Hany El-Said, 2004). Meat from of fresh fish flesh are the most common source of high protein food and important source of protein in human nutrition (Youssef et al., 2007). There are many fish sources in Yemen (Red sea in the west, Arab sea in the south). In Yemen most of people from lack of meat, hence the local consumption decreased daily (day by day). Some of villages in Republic of Yemen have not electric 
current and they stored their Fish at air condition in retail stores so that it loss many of nutritious value. Storage of food at high temperature also to cause a loss of nutritional value. The chemical composition of the food and the metabolic activates of the organisms growing in the food determine the compounds which can be used as indicators, because of the extreme perish ability of some products, occasionally decomposed foods get into market channels (Sayed, 2002), so the object of our present investigation is to evaluate sum quality parameters of high nutrition and anther chemical composition in Yemeni fish, determination of different total bacterial counts of tested samples were carried out, the total number of microorganisms present did appear to be high during storage at room-temperature. Also the aim of this study could be mentioned as follows: (1)-To find out the degree of bacterial contamination of fish, this is given the term bacteriological flow sheet. (2)-Effect of storage at room temperature on the different microbiological, physical and chemical quality of local fresh fish meats. (3)-To find out the chemical nutritional characteristics of the samples under investigation

(4)-Evaluate the microbiological, physical and chemical quality of fresh fish meats in retail markets. (5)-Isolation and identification of Bacillus species of all tested samples as a selection of fish meats contamination.

\section{MATERIALS AND METHODS}

\section{1- Materials (preparation and storage of samples)}

Ten kilogram of fresh fish $\}$ its common name in Republic of Yemen is (Gahsh), and its scientific name is (Lethrinus elongates. The samples were collected and purchased from different local retail stores in Taiz city (Republic of Yemen), the whole Fish flesh were immediately to remove the skin surface slime, dirt, head, wing, viscera, fins and skeleton were removed and any residual blood were also removed after that the samples immediately transferred in icebox to the microbiology laboratory (Faculty of Science, Taiz University) and divided to small retail severance meat (each severance meat contain 50 grams), and directly storage at room temperature $\left(30^{\circ} \mathrm{C}\right)$, the bacteriological, physical and chemical changes were followed examination of retail severance of fresh fish meats carried out at zero time (as a control samples) within $2 \mathrm{hr}$ and day by day (every day) during storage at room temperature for three (3) days, until signs of spoilage appeared by the border line of fish meats acceptability for total microbial count was found to be $(<108)$ cell/g and appearance of putrid smell as reported by Microbiological Criteria for Arabia and Egyptian Standard Food (Hany, 2004 and El-Shamery, 2007).

\section{2- Methods:}

\section{A- Chemical and physical analysis}

Moisture content (M.O), Total nitrogen (P.R), Crude fat and ash content were determined according to method described by A.O.A.C, (2002). Total Carbohydrate (C.B) were calculated by the differences according to Egan et al., (1981), as follows: [Total carbohydrate $=$ $100-(\%$ Moisture $+\%$ Protein $+\%$ Fat + $\%$ Ash $)=(\%$ Gram per 100 gram on dry weight basis). Total volatile bases nitrogen (T.V.N), Trim ethyl amine nitrogen (T.M.A) and Ammonia nitrogen (A.N) were determined according to the method mentioned by A. M.C, (1979) (Mg per/ 100gm sample on dry weight basis. Thiobarbituric acid (T.B.A) was determined as indicated according the method of Siu and Draper, (1978) mg mono aldhyed per 100 gram sample on weight basis. The $\mathrm{pH}$ value was measured according to method described by Krilova and Liskovskain, (1961). Energy value was calculated according to the equation given by Winton and 
Winton, (1958). Water holding capacity (W.H.C), and Water bound (B.W), were measured by following the filter press method of Gram and Hamm, (1957) as described by Soloviev, (1966).

\section{B- Microbiological examination}

Twenty five grams from (randomly samples) of the fish meats were blended with $225 \mathrm{ml}$ of $0.1 \%$ peptone water in a sterile blender jar for 1-2 minutes and decimal dilutions prepared for testing. numbers of viable organisms were determined by the plate count method. One ml of each dilution was inoculated with appropriate media for the particular group of organisms to be tested as (Colony forming unit per gram (c.f.u/g). The total aerobic bacterial count was determined according to A.P.H.A, (1992) using plate count agar medium incubated at $37^{\circ} \mathrm{C}$ for 3-5 days. Anaerobic bacterial count was determined by A.P.H.A, (1992) using cooked meat agar medium with anaerobic jars (Gas pak system by B. BL cockysville marland 21030 USA). Yeasts and moulds were counted on malt extract agar medium (Oxoid, 1985) incubated at $25-30^{\circ} \mathrm{C}$ for $3-5$ days as described by Pitt and Hocking, (1985). Spore former bacteria were determined according to method described by Chalmers, (1955) the suitable dilution were subjected to $80^{\circ} \mathrm{C}$ at $20 \mathrm{~m}$ for $48-72 \mathrm{~h}$. proteolysis bacteria inoculation were made TGY to which $10 \%$ (10 ml / $100 \mathrm{ml}$ medium) of sterile skim med milk has been added just before pouring plates were incubated for 2-3 days at $30^{\circ} \mathrm{C}$ (A.P.H.A, 1992). Streptococcus spp bacterial count was determined by used Dried brain heart infusion agar and Ma Cconky agar media (Oxoid, 1985) the inoculums was spread on the surface of plate, after incubation at $37 \mathrm{oC}$ for $24-48 \mathrm{~h}$, as mentioned by Mossel and Tamminge, (1980). Enterobacteriaceae was determined on Violet red blue dextrose agar medium after incubation at $37^{\circ} \mathrm{C}$ for $20-24 \mathrm{~h}$, as described by Robert et al., (1995).
Bacillus spp was counted by using Manitol egg yolk-poly mixing (MYP) agar and incubation for $16-24 \mathrm{~h}$, at $37^{\circ} \mathrm{C}$ as described by Roberts et al ., (1995) . Salmonella spp was carried out using the most probable number technique (M.P.N) according to (ISO, 1982), after enrichment at $37^{\circ} \mathrm{C}$ for $24 \mathrm{~h}$, in Silent broth, the cultures were streaked on Brilliant green agar and incubated at $37^{\circ} \mathrm{C}$ for $24 \mathrm{~h}$, then colonies were biochemical examined in Triple sugar iron agar (TSI) and Lysine carbonate broth. Staphylococcus spp was enumerated on Baird-parker medium using surface plating technique as recommended by I.A.E.A, (1990), incubated at $37^{\circ} \mathrm{C}$ for $24 \mathrm{~h}$. Enterococci spp was enumerated on Konamycin insulin aside agar medium (Mossel and Tamminge, 1980) positive colonies were confirmed by Microscopic examination for the presence of short chain streptococci. Coli form group was counted used the ( M.P.N ) method as reported by I.A.E.A, (1990), by inoculating MaCconkey agar medium incubated at $44^{\circ} \mathrm{C}$ for 24-48 h. Clostridum spp used Cooked meat agar medium incubated at $37^{\circ} \mathrm{C}$ for $24 \mathrm{~h}$. in anaerobic system using gas generation kit as mentioned by Cravene et al., (1979) and Oxoid, (1985).

\section{C- Isolation and identification of Bacillus spp}

Isolation and identification of Bacillus spp were determined from total count plates (APT) agar (A.P.H.A, 1992) colonies in opposite sectors, were picked and transferred to agar slants of the same medium, alter purification, bacterial grouping according to morphological characteristics and Gram stain was carried out. Gram- positive groups were identified to generic and species level with the aid of Bergey's Manual for Systematic Bacteriology, (1986); Kotzekidou, (1996) and Bergey's Manual of Determinative Bacteriology, (1999). The method of identification adopted for 
this purpose genus Bacillus with standard tests and classification schemes described by Smith et al., (1952), in conjunction with and examination were carried out according to Holt et al., (1986).

\section{RESULTS AND DISCUSSION}

A-Chemical and physical analysis of fresh fish meat during storage at room temperature.

Table,(1)showed the effect of storage at room temperature on Moisture (M.O), Protein (P.R), Fat, Ash, Total carbohydrates contents (C.B), and chemical indicates for spoilage ie $\mathrm{pH}$, Total volatile bases nitrogen (T.V.N), Tri methylamine (T.M.A), Ammonia nitrogen (A.N), Thiobarbituric acid
(T.B.A), Total calories[Energy value(E.N)] and Water holding capacity (W.H.C) it determination as abound water (B.W) of local fresh fish meat for a 3 days of storage at this stage of storage the control samples were completely rejected by the border line of fish meat, acceptability for total microbial count, table, (2) was found to be [>108] cell /g and appearance of putrid smell as reported by microbiological and chemical criteria for Arabia and Egyptian Standard Food and by Shawki, (1998); Shady, (1999); El-Feky, (2002); Hany El-Said, (2004); Abd-El-Daim, (2004); Youssef et al.,(2007) and Ibrahim et al., (2009).

Table 1: Effect of storage at room temperature on chemical composition and physical properties of local fresh fish meats.

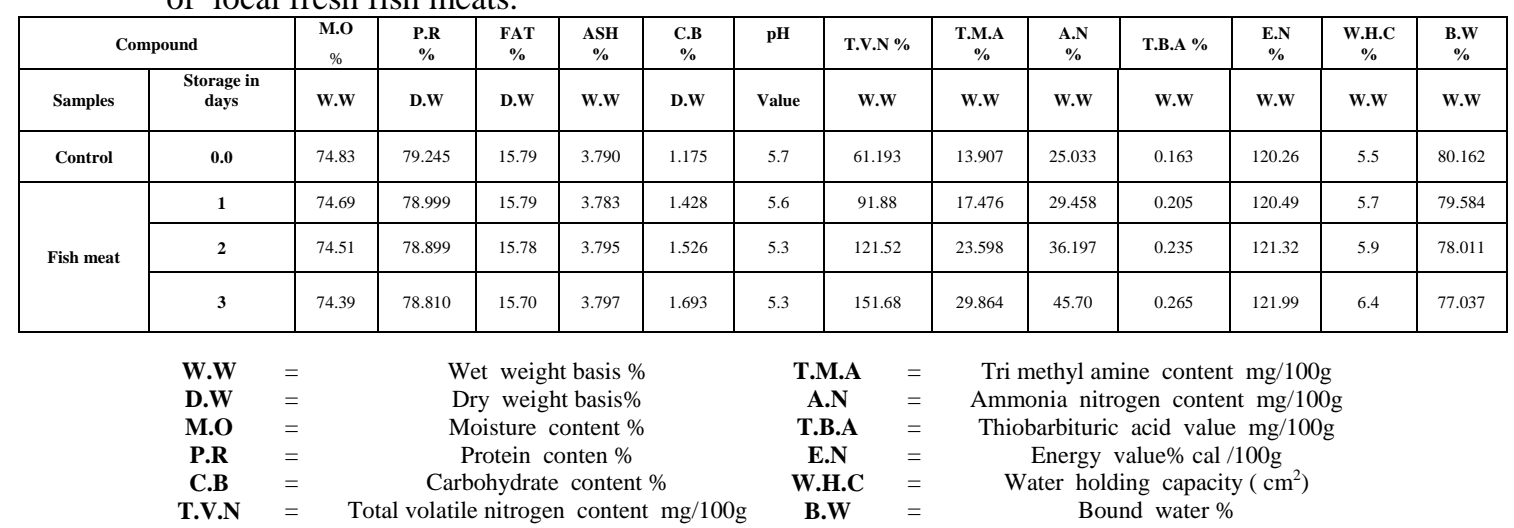

Table 2: Effect of storage at room temperature on microbiological properties of local fresh fish meats.

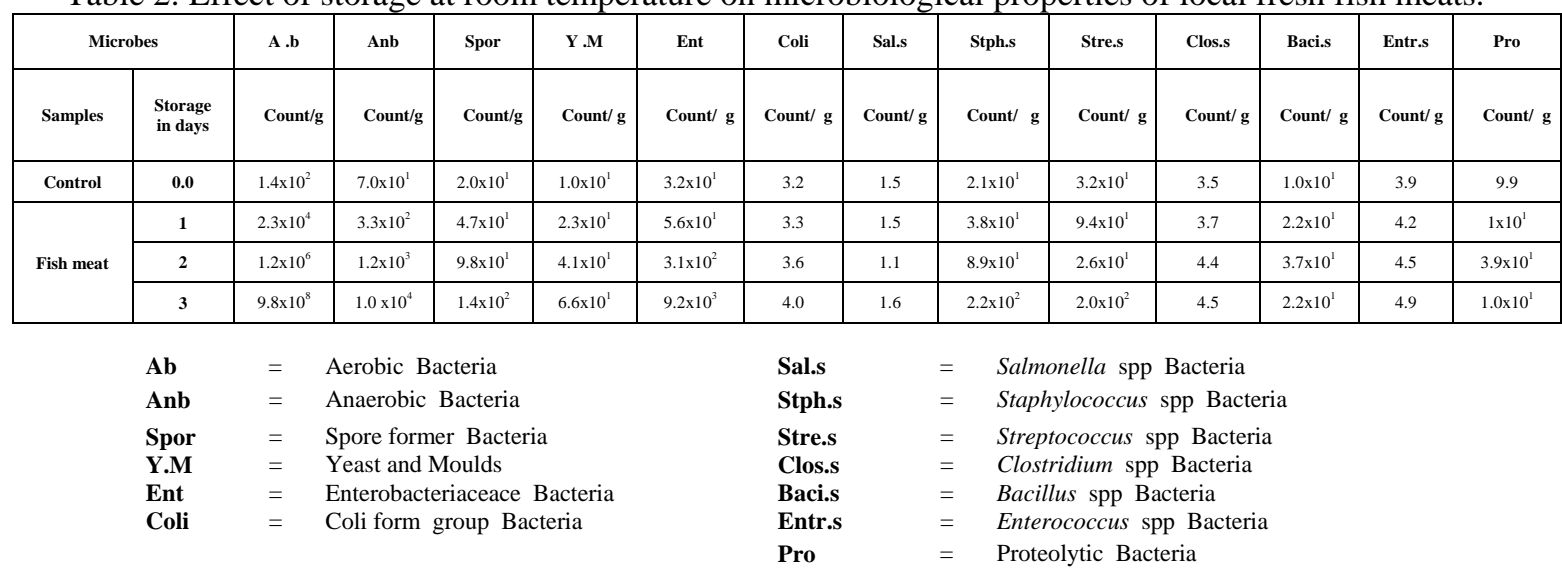


From data in table, (1) it could be notice the Moisture (M.O), Protein (P.R), Fat, Ash, Carbohydrate) C.B), $\mathrm{pH}$ value, Total volatile nitrogen (T.V.N), Tri methyl amine (T.M.A), Ammonia nitrogen (A.N), Thiobarbituric acid (T.B.A), Total calories [Energy value (A.N)], Water holding capacity (W.H.C) and Bound water (B.W), on control samples at 0.0 time of storage were, $74.83 \%, 79.24 \%, 15.79 \%, 3.79 \%$, $1.17 \% \mathrm{mg} / 100 \mathrm{~g}, 5.7 \mathrm{pH}$ value, $61.193 \%$, $13.907 \%, 25.033 \%, 0.163 \% \mathrm{mg}$ per $/ 100 \mathrm{gm}$, $120.26 \% \mathrm{mg} \mathrm{cal} / 100 \mathrm{~g}, 5.5 \%$ and $80.162 \%$ of fish meat respectively. These results were in agreement with the chemical criteria for Arabia and Egyptian Standard Food and within the range of values of fresh fish meat as reported by Nessrin, (1997); El-Mongy et al., (2001); Ibrahim et al., (2009) and Gamal El-Deen, (2007).

Regarding to the room temperature storage the Moisture, Protein, Fat ,Bound water and $\mathrm{pH}$ value changes were slightly decreased with storage time increased being at first day of storage $74.52 \%, 78.44 \%$, $15.70 \%, 79.58 \%$ and $5.6 \mathrm{pH}$ value of fish meat respectively and decreased throughout storage to reached at end of storage to 74.22 $\%, 78.81 \%, 15.69 \%, 77.037 \%, 5.3 \mathrm{pH}$ value after 3 days of storage for fish samples respectively these results were in agreement with finding with [Min et al., 1998; Ahn et al., 1999 and Bader, 2004]. In the other words it is means the decreasing percentages were $0.81 \%, 0.54 \%, 0.63 \%, .89 \%$ and $7.0 \%$ for the Moisture, Protein, Fat, Bound water and $\mathrm{pH}$ value of the above mentioned samples comparing with the control samples respectively, these decrease in moisture content of above samples may be due to evaporation of water during storage, these results agree with [Affi and El-Nashaby, 2001; El-Shamery, 2007 and Kanatt et al., 2009]. As well as the decrease of Protein content in same samples may be due to the loss of nitrogen as volatile bases and nitrogenous substances, more over, the decrease of protein loss might be meanly attributed to decomposition of meat by higher load of micro organisms which formed volatile nitrogenous substances and soluble substances by the effect of proteins that escaped from the tissues during storage as results agree with [Hammad, 1995; Nam and Ahn, 2003 and El-Shamery, 2007]. Also, the decreased in Fat content of above samples may be due to oxidation and hydrolysis by activity of microorganism, leading to the conversion of part of lipids into aldehydes, ketenes and other non fatty substances. As agree with [Anon, 2000; Du et al., 2001 and Lee et al., 2005]. Mean while, the decreased in Bound water (B.W) of above samples were attributed to protein denaturalize according to [Silva and Chamul, 2000; El-Shourbagy, et al., 2003; Youssef et al., 2007 and Kanatt, et al., 2009]. More over, the decreased of $\mathrm{pH}$ value in above fish meats could be due to formation of lactic acid and break down of glycogen. This as findings of [El-Hanafy and Amira, 2001; Bassiouny et al., 2002 and Aycicek et al., 2004]. In addition, it is clear from table,(1) illustrate the total Carbohydrate (C.B), total Volatile nitrogen (T.V.N), Tri methyl amine (T.M.A), Ammonia nitrogen (A.N)content, Thiobarbituric acid value (T.B.A), total Calorie [Energy value (E.N)] and Water holding capacity (W.H.C) changes were increasing during storage at room temperature with storage time increased, they were in the beginning [at first day of storage] $2.072 \%, \quad 91.88 \%, \quad 17.476 \%, 29.458 \%$, $0.205 \%, 120.499 \%$ and $5.7 \%$ of fish meat respectively, and increasing through storage to reached at end of storage to $1.703 \%, 151.68 \%, \quad 29.864 \%, \quad 45.70 \%$, $0.265 \%, 121.99 \%$ and $6.4 \%$ after 3 days of storage for fish meat respectively, such results were in agreement with [Du and Ahn, 2002; Yilmaz et al., 2002; El-Shamery, 2007 and Lacroix et al., 2009]. In the other words, it is means the increasing percentages were $43.97 \%$ for Carbohydrate content (C.B), $147.87 \%$ for total Volatile nitrogen (T.V.N), $114.74 \%$ for Tri methyl amine (T.M.A), $82.55 \%$ for Ammonia nitrogen content (A.N), 62.57\% for Thiobarbituric acid, $1.43 \%$ for total Calories [Energy value (E.N)] and $16.36 \%$ for Water holding capacity of the previous samples respectively comparing with the control samples. These increased of energy may be due to increased of carbohydrate content and evaporation of 
water from the meat as results agree with [Hammad, 1995 and El-Shamery, 2007], Also that increasing in Carbohydrate during storage at room temperature may be due the natural feeding which resulted increase of glycogen in muscles or may be due to evaporation of water from the outer surface of meat. These results agree with [Zayas, 1997; Ali, 2004 and Gamal El-Deen, 2007]. More over, the results of increasing the total Volatile nitrogen (T.V.N) as an index of the degree putrefaction, decomposition and the degree of protein genoas break-down as well as protein outlays hank outlays and breaker decomposition, resulted in the high level of total volatile nitrogen (T.V.N) according by these results were going parallel with [ElShamery, 2001; Nam and Ahn, 2003 and ElShamery, 2007]. Mean while, increasing of Tri methyl amine (T.M.A) in above samples could be due to break down of amino acids, phospholipids as lecithin and Tri methyl amine (T.M.A), these result agree with, [Shawki, 1998; Affi and El-Nashaby, 2001; El-Shamery, 2007 and Kanatt et al., 2009]. As well as, the increasing on Ammonia nitrogen (A.N) may be due to break down of proteins through proteolysis and decomposition by higher rate of microorganism as reported by Shady, (1999); El-Shamery, (2001); Hany El-Said, (2004); Lee et al., (2005) and Gamal El-Deen, (2007).

\section{B- Microbiological quality of local fresh fish meat during storage at room temperature.}

The quality of fresh fish meat are largely dependent on their microbial contamination during sliding, handling marketing and on storage temperature as reported [Affi and ElNashaby, 2001 and Gamal El-Deen, 2007]. The results in (table, 2) showed the effect of storage at room temperature on total differential counts of Aerobic (A.b), Anaerobic (Anb), Spore formers bacteria (Spor), Yeast and Moulds (Y.M), Enterobacteriaceace (Ent), Coli form groups (Coli), Salmonella spp (Sal.s), Staphylococcus spp (Stph.s), Streptococcus spp (Stre.s), Clostridium spp (Clos.s), Bacillus spp (Baci.s), Enterococcus spp (Entr.s) and Proteolysis bacteria (Pro), as (colony forming unit per gram c.f.u/g) of fresh fish meat. The data in (table, 2) show that the initial organism counts of control samples [at zero time of storage] were $1.4 \times 102, \quad 7.0 \times 101, \quad 2.0 \times 101, \quad 1.0 \times 101$, $3.2 \times 101,3.2,1.5,2.1 \times 101,3.2 \times 101,3.5$, $1.0 \times 101,3.9$ and 9.9 c.f.u/g for a fish meat samples of above microbes respectively. This value is within the range of values of fresh fish meat as reported by Microbiological Criteria for Arabia and Egyptian Standard Food and by Shawki, (1998); El-Feky, (2002); Hany El-Said, (2004); Lee et al., (2005) and El-Shamery, (2007). From same data in (table,2) indicates also that the differential microbial counts were a gradual increasing during storage with the time of storage increasing it being at first day of storage $2.3 \times 104,3.3 \times 102,4.7 \times 101,2.3 \times 101$, 5.6x101, 3.3, 1.5, 3.8x101, 9.4x101, 3.7, 2.2 $\mathrm{x} 101,4.2,1 \times 101$ c.f.u/g and reached to $9.8 \times 108, \quad 1.0 \times 104, \quad 1.4 \times 102,6.6 \times 101$, $9.2 \times 103,4.0,1.6,2.2 \times 102,2.0 \times 102,4.5$, $2.2 \times 101,4.9$ and $1.0 \times 101$ c.f.u/g after 3 days end of storage period on fish samples of above microbes respectively. However, the samples were rejected after 3 days of storage, and at this stage, all the other counts of microbiological examination were closed, this rejection of samples depended up on the total Aerobic bacteria counts to reached at [>108] cells/g and appearance of putrid smell also by the border line of fresh fish meat acceptability as reported by Microbiological Criteria for Arabia and Egyptian Standard Food and by Gillespie et al., (2000); Jackson et al., (2001); Eleftheriadou et al., (2002 ; Hany El-Said, (2004); Ali, (2004) and El-Shamery, (2007). In the other words it is means the increasing percentages were $68.56 \%, 43.20 \%, 26.75 \%, 28.82 \%, 49.59 \%$, $16.66 \%, 15.00 \%, 30.53 \%, 24.24 \%, 16.92 \%$, $14.52 \%, 14.49 \%$, and $50.50 \%$. of above microbes respectively. This increasing in the total bacterial counts during storage at roomtemperature were expected as the fresh fish meats are considered of the most perishable food that is highly susceptible to microbial invasion and the great increasing in bacterial load is mainly due to the direct and in direct effects of higher temperature of storage on microorganism, these agree with [Bennett, 2001; Fang et al., 2003; Aycicek et al., 2004; Lee et al., 2005 and Gamal El-Deen, 2007 [ .In addition, it is clear from same (table, 2) that total Aerobic bacterial counts (A.b) was the higher than anther bacterial counts on control samples, also the Salmonella spp 
(Sal.s), Coli form groups(Coli), Clostridium spp (Clos.s) and Enterococcus spp (Entr.s), counts were lower levels of counts compared with other counts (on the control or all the samples during storage). The total Aerobic bacterial counts (A.b) and the Proteolysis bacteria counts (Pro) were the higher than anther bacterial counts during storage compared with other counts on all the samples these result agree with [Hammad, 1995; Satin, 2002; Hany El-Said, 2004; Gamal El-Deen, 2007;

El-

Shamery, 2007; Kanatt et al.,2009 and Ibrahim et al., 2009].

C- Isolation and identification of Bacillus species.

Isolation and identification of Bacillus species were clear in (Table,3) results in table (3) illustrate the Groups of bacterial Bacillus spp identification, Numbers of isolates, Percent distribution (total isolates), physiological and biochemical characteristics of the Bacillus species isolated from local fresh fish meats, in same table, (3) indicated that seventeen bacterial isolates, these bacterial isolates are classification and divided into six groups, all these groups are subjected to extensive toxin cal studies and identified into deferent seventeen species, identified of these groups and their obtained from as following: Group one was obtained three species of (Bacillus subtilus), their percentage are $(17.647 \%)$ of total isolates.Group two was (Bacillus pumilus) their number of isolates was two and their percent distribution was (11.764\%). Group three was four species of (Bacillus cireulans), their percentage was $(23.53 \%)$ of total isolates group four was three species of (Bacillus lentus) obtained by (17.647\%) of total isolates.

Table 3: Numbers of groups, Bacillus spp identification, numbers of isolates, percent distribution physiological and biochemical characteristics of the Bacillus species isolated from samples under investigation.

\begin{tabular}{|c|c|c|c|c|c|c|c|c|c|c|c|c|c|c|c|c|c|c|c|c|c|}
\hline \multirow[b]{2}{*}{ 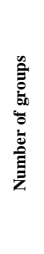 } & \multirow[b]{2}{*}{$\begin{array}{l}\text { Bacillus spp } \\
\text { identification }\end{array}$} & \multirow[b]{2}{*}{ 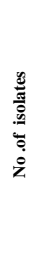 } & \multirow[b]{2}{*}{ 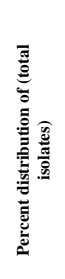 } & \multicolumn{18}{|c|}{ physiological and biochemical characteristics } \\
\hline & & & & 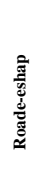 & 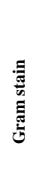 & 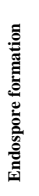 & 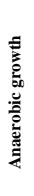 & $\begin{array}{l}\overrightarrow{\mathrm{g}} \\
\stackrel{\mathrm{g}}{\mathrm{c}}\end{array}$ & 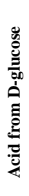 & 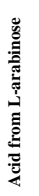 & 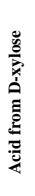 & 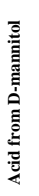 & 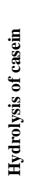 & 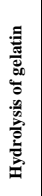 & 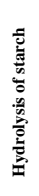 & 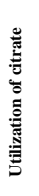 & 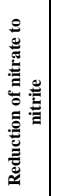 & 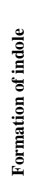 & 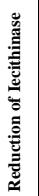 & 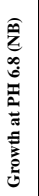 & 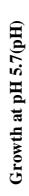 \\
\hline G1 & Bacillus subtilus & 3 & 17.647 & + & + & + & - & + & + & + & + & + & + & + & + & + & + & - & - & + & + \\
\hline $\mathrm{G} 2$ & B.pumilus & 2 & 11.764 & + & + & + & - & + & + & + & + & + & + & + & - & + & - & - & - & + & + \\
\hline G3 & B. cireulans & 4 & 23.53 & + & + & + & - & - & + & - & - & - & + & + & - & + & - & - & - & + & - \\
\hline G4 & B. lentus & 3 & 17.647 & + & + & + & - & - & + & + & + & + & - & + & - & - & + & - & - & + & - \\
\hline G5 & B. macerans & 4 & 23.53 & + & + & + & + & - & + & + & + & + & - & + & + & - & + & - & - & + & + \\
\hline G6 & B. cereus & 1 & 5.882 & + & + & + & + & + & + & - & - & - & + & + & + & + & + & - & + & + & + \\
\hline \multicolumn{2}{|c|}{ Total .No of Bacillus spp } & 17 & $100 \%$ & & & & & & & & & & & & & & & & & & \\
\hline
\end{tabular}

Group five was four species of (Bacillus mecerans) by (23.53\%) of total isolates. Group six was one species only of (Bacillus cereus) obtained from total isolates by $(5.882 \%)$. On the basis of morphological, biochemical and physiological characteristics and their identified as above and in table, (3) were according to Bergey's Manual for Systematic Bacteriology, (1986); Kotzekidou, (1996) and Bergey's Manual of Determinative Bacteriology, (1999), the classification schemes described by Smith $e t$ al.,(1952) in conjunction with ( Holt et al., 1986).

\section{REFERENCES}

Abd El-Daiem, M.H. (2004). Keeping the quality of ready-to-eat meals by gamma irradiation. Ph.D. Thesis. Fac. of Agric. Moshtohor. Zagazig Univ . Egypt.

Afifi, E. A and El-Nashaby, F.M.(2001). Microbial decontamination of some chicken meat products by gamma irradiation. Arab. J. of Nuclear Sci and Appl (ISSN 1110-0451.) Periodical of the Egyptian Society of nuclear 
Sciences and Application. 34(1) January (2001).

Ahn, D.U; Olson, D.G; Love, J.C and Jin, S.K. (1999). Volatiles production and lipid oxidation in irradiated cooked sausage as related to packaging and storage. J. Food Sci. 64 (2): 226

Ali, H. E. (2004). Production of imitated fish and keeping their quality by gamma irradiation. Ph. D. Thesis. Fac. of Agric. Moshtohor, Zagazig Univ. Egypt.

A. M. C. (1979). Analytical method committee recommended method for the examination of fish and fish products.Analyst, 104,434. Public health laboratory service (PHLS). Communicable .

Anon (2000). Food Irradiation. J. Am. Diet. Assoc., 100:246.

A. O. A. C. (2002). Association of official analytical chemists, official method of analysis, $17^{\text {th }}$ ed. A.O.A.C. International, Washington. D.C, USA.

A. P. H. A. (1992). Compendium of methods for the microbiological. examination of foods, 3rd edn. Amer. spp (Stph.s), Public. Health Assoc. Washington.

Aycicek, H.; Sarimehmetoglu, B. and Cakiroglu, S. (2004). Assessment of the microbiological quality of meals sampled at meal serving unite of a military hospital in Ankara, Turkey. Food control, 15, 379.

Bader, H. M. (2004). Use of irradiation to control food borne pathogens and extend the refrigerated market life of fish meat, Meat Sci., (67), 541 , Egypt.

Bassiouny, S.; Bader, F.; Ahmed, K.; Afifi, E. and El-Hanafy, A. (2002). Physiochemical and microbiological properties of irradiated formed surmise during cold storage. Egypt. J. Microbial. 2:33-42.

Bergey‘s. (1986). Manual of Systematic Bacteriology. Vol. 2.Eds (snatch, pH, Maier, N.S, Sharpe, E.M) Williams \& wilkins, London, Los Angles, Sydney.

Bergey's. (1999). Manual of Determinative Bacteriology. Eighth, Edition Ed CR. E. Buchanan \& N.E. Gibbons, the Williams \& wilkins company. Built make.

Bennett, R.W. (2001). Bacillus cereus. In: Labia, R. G. and Garcia, G. (eds), Guide to food borne pathogens, $\operatorname{spp}($ Stph.s),eely. Inter science, New York, Ch. 4, pp.51.

Chalmers, C. H. (1955). Bacteria in relation to milk supply 4th.Ed. Edward Arnold ltd. London.

Cravene, E. S.; Lillard, H. S. and Mecuri, A. J. (1979). Survival of Clostridium perfringens during preparation of precooked chicken parts .J. food Tech. 38:505-508.
Du, M. and Ahn, D. (2002). Effect of antioxidants on the quality of irradiated sausages prepared with turkey thigh meat poultry Sci, $81(8)$ : 1251.

Du, M.; Hur, S.J.; Nam, K.C.; Ismail, H. and Ahn, D. U.(2001). Volatiles, color, and lipid oxidation of broiler breast fillets irradiated before and after cooking. Polite Sci. 80(12): 1748 .

Egan, H.; Kirk, K.S. and Sawyer, R.(1981). Pearson,s chemical analysis of foods. 8th edn., Churchill Livingstone, Ed in burg.

Eleftheriadou, M.; Varnava, A.; Metta-Loizidou, M.; Nikolaou, A. and Akkeldou, D. (2002). The Microbiological profile of foods in the Republic of Cyprus: 1991-2000.Food Microbial, 19, 463.

El-Feky, M. S. (2002). Chemical and microbiological quality of some foods. $\mathrm{Ph}$. D. Thesis. Fac. of Agric. Moshtohor, Zagazig Univ, Egypt.

El-Hanafy and Amir, A. (2001). Technological and chemical studies on fish and fishery products. Ph.D. Thesis, Fac. of .Agric, Zagazig Univ. Egypt.

El-Mongy, T. M.; Sallam, Y. I.; Salwa, B. M.; ElMagoli and Haman, H. M. (2001). Irradiation of frozen mincemeat for public heath protection . Egypt. J. Rad. Sci. Appl. $14(1), 95$

El-Shamery, G. R. (2001). Studies on spoilage of some foods. Ph. D. Thesis. Fac. of Agric. Moshtohor. Zagazig Univ. Egypt.

El-Shamery, G. R. (2007). Studies on microbiological, physical and chemical quality of cow meats during storage. Egypt. J. of Appl. Sci., 22 (6A). 2007. 78- 93.

El-Shourbagy, G.; Bassiouny, S. S. and ElHanafy, A. E. (2003). Effect of different washing methods on the quality characteristics of minced catfish intended for surmise processing. Zagazig. J .Agric. Res., Vol. 30 No. (6) PP. 2357-2369.

Fang, T.J.; Wei, Q.K.; Liao, C.W.; Hung, M. J. and Wang, T.H.(2003). Microbiological quality of $18^{\circ} \mathrm{C}$ ready to eat food products sold in Taiwan. Int . J. Food Microbial. 15; 80 (3): 241.

Gamal El-Deen, M. R. (2007). Microbial decontamination and improving the quality of frankfurter by gamma irradiation and cold storage. Minufiya, J. Agric. Res. 32(3): 799-815 June( 2007 ). ISSN 1110-0265. Minufiya Univ., Egypt

Gillespie, I.; Little, C. and Mitchell, R.(2000). Microbiological examination of cold readyto-eat sliced meats from catering establishments in the Unite Kingdom. J. Appl. Microbial. 88(3):467 
Gram, R. and Hamm, F. (1957). Uber das wassebindung svermogen dessaugetiermuskelsUber das.11 uber diebe stimmugder wasserbindung desmuskels. Z. Lebens mittel untersucund Forschung, 105(6):446-460.

Hammad, A. A. I. (1995). Chemical, physical and microbiological changes in different fish products preserved by different methods including irradiation. Ph.D. Thesis. Fac, of. Agric. Cairo Univ. Egypt.

Hany El-Said, S. A. (2004). Production of imitated fish and keeping their quality by gamma irradiation. Ph.D. Thesis. Fac of Agric. Zagazig Univ. Egypt.

Holt, J.G.; Sneath, P. H.; mair; Nair, N. S. and Sharp, M. Elisabeth. (1986). Berger's manual of systematic bacteriology Vol. (2) Section 13 Endo-spore-22.

I. A. E. A. (1990). Microbiological specification and testing methods for irradiated foods. Technical Report series No. 104, I. A. E. A, m Vienna.

Ibrahim, Y.; Sinan, U. and Ayhan, T. (2009). Effect of gamma irradiation on some principle microbiological and chemical quality parameters of raw Turkic meat ball. Food control.

ISO. (1982): International Organization for Standardization. 1208

Jackson,T.C.; Acuff, G. R. and Dickson, J. S. (2001). Meat, poultry and seafood. In: Doyle, M. P., Beached, L.R. and, Montville, T. J. (eds) Food Microbiology Fundamentals and Fronts. Washington, D. C; ASM Press. Ch.5, pp.83.

Kanatt, S.R.; Chander, R. and Sharma, A. (2009). Effect of radiation processing on the quality of chilled meat products. Meat Science, (In press).

Kotzekidou, P. (1996). A micro titer tray procedure for simplified identification of Bacillus spp. In spoiled Canned foods. Food microbiology, 13: 35- 40.

Krilova, N. N. and Liskovskaia, U. N. (1961). Fiziko Khimicheskie Metodiess Ledovonia Prodooktov Jirotnova Proyskhoj Clenia, Piskipromez date, 1961, Moskva. Physicochemical methods for the investigation of the products of Animal source. Food industry pub. Moscow.

Lacroix, M.; Ouattara, B.; Saucier, L.; Giroux, M. and Smoragiewicz, W. (2009). Effect of gamma irradiation in presence of ascorbic acid on microbial composition and TBARS concentration of ground beef coated with an edible active coating. Rad. Phy. and Chem.(In Press).

Lee, J.; Yook, H.; Kim, S.; Lee, H. and Byun, M. (2005). Effect of antioxidants and gamma irradiation on the shelf of meat patties. J. Food Prot.; 62 (6):619.

Min, J. S.; Shin, D. K.; Lee, S. O.; Lee, J. I.; Kim, I. S. and Lee, M. (1998). The effect of gamma irradiation on Rabbit breast quality. Korean, J of Animal Sci.; 40(6):661-670 .

Mossel, D. A. and Tamminge, S.K.(1980). Method for Microbiological Examination of Food (in Deutch). Zeist (1980).

Nam, K.C. and Ahn, D. U. (2003). Mechanisms of pink color formation in irradiated precooked turkey breast. J food, Sci., 67(2):600-607.

Nessrien, M. N. (1997). Studies on the expiration period and quality alttributes of some fish products. M. Sci Thesis, Fac. of Agric. AinShams Univ. Egypt.

Oxoid, (1985). The oxide manual of culture media ingredients and other laboratory services. Oxide Limited, Hampshire, England St.

Pitt, J. I. and Hocking, A. D. (1985). Fungi and food spoilage. Academic press, bub. Sunday, New York, London 1985.

Roberts, D.; William, H. and Melody, G. (1995). Practical food microbiology. PHLS, London .Int. 34, 449.

Shawki, H. A. S. (1998). Influence of ionizing radiation on fish products. M. Sci. Thesis. Food Sci, Dept. Fac, of Agric Zagazig Univ. Egypt.

Shady, H. M. A. (1999). Studies on the preservation of frozen meat and poultry $\mathrm{M}$. Sci. Thesis, Fac, of Agric .Ain-Shams Univ. Egypt.

Sayed, S. A. (2002). Studies on baby foods. M. Sci. Thesis, Food science and technology Dept., Fac of Agric. Assiut Univ. Egypt.

Silva, G. L. and Chamul, R. S. (2000). Composition of marine and fresh water finfish and shell fish species In, Marine Fresh water products Hand book (eds) Martin, R. E.; Carter, E. P.; Flick, G. J. and Davis, L. M., Techno. pub.

Siu, M. G. and Draper, H. H. (1978). A survey of the malon-aldehyde content of retail meats and fish. J. Food, Sci. 43:147-1149.

Smith, N. R.; Gordon, R. E. and Clark, F. E. (1952). Aerobic spore-forming bacteria agricultural monograph. No.16.U.S.A. Dept of Agric.

Soloviev, B. E. (1966). Meat Aging. Food Industry Pub., Moscow. A. E. MFG.

Satin, M. (2002). Use of irradiation for microbial decontamination of meat: situation and perspectives. Meat Sci., 62, 277.

Winton, A. L. and Winton, R. B. (1958). Okoloff magnesium oxide distillation volumetric method "The analysis of foods" P.848, Jon wiley New York and Japan, London. 
Youssef, M. K.; Magda, A. A.; Seleim, M. B.; Omar, A. and Hesham, Z. T. (2007). Nutritional assessment of new six school student formulae based on some cereals and legumes. Assiut. J of Agric. Sci., 38 (4): 65- 84.

Yilmaz, I; Yetim, H. and Ockerman, H. W. (2002). The effect of different cooking procedures on microbiological and chemical quality characteristics of Turk dog meat balls. Nahrung.46 (4), 276.

Zayas, J. F. (1997). Water holding capacity of proteins, Ch.2 In, Functionality of proteins in food Springer-Vera lag Berlin.

\section{ARABIC SUMMARY}

\section{دراسات عن تلوث و جودة لحوم الاسماك الطازجة خلال التخزين

\author{
جمال الدين محمد رسام الثميرى \\ قسم الميكروبيولوجيكلية العلوم جامعة تعز الجمهوريه اليمنيه
}
تهد ف هذة الدراسة لمعرفة الجودة ومدى التلوث الميكروبيولوجى و الطبيعى و الكيمائى للحوم الاسـماك الطازجة

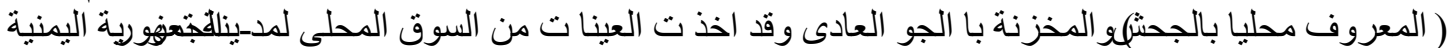

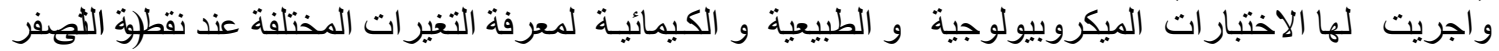

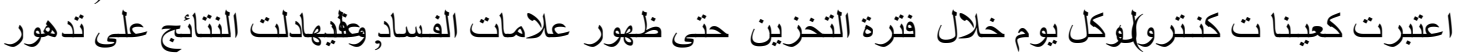

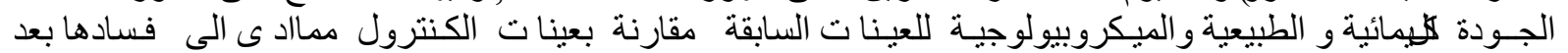

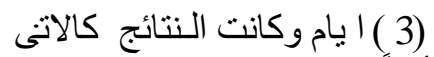

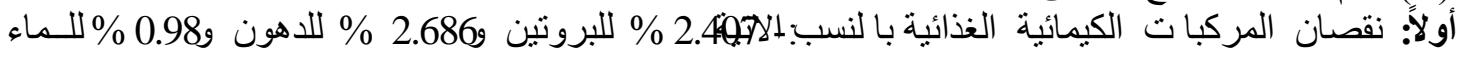

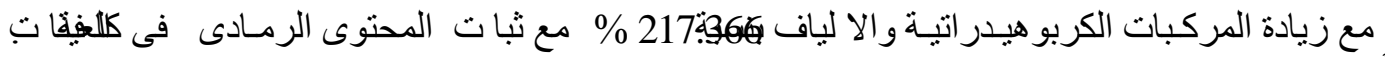

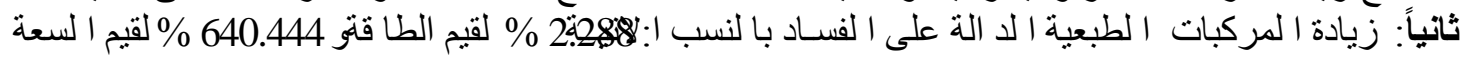

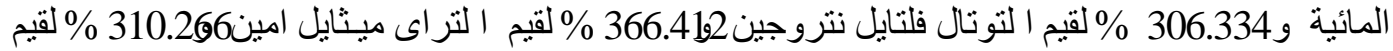

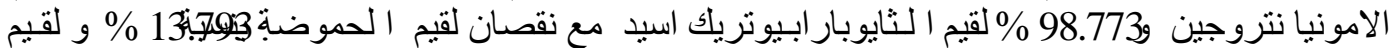

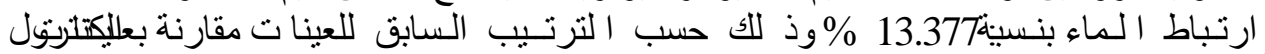

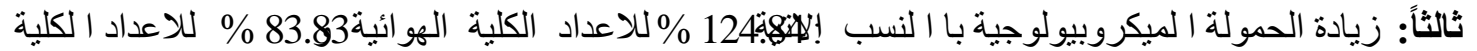

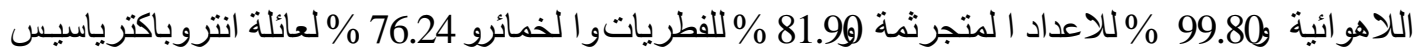

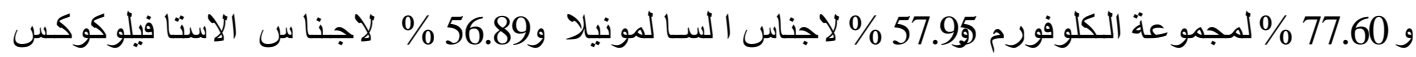

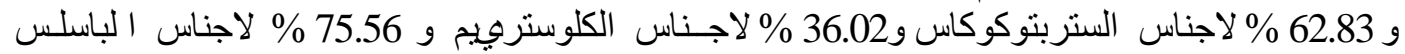

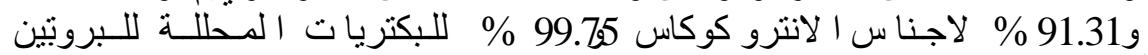 رابعلُّ تم عزل(17) ميكروبا صنفت تبعا لاجناس باسلس كن كن كافة العينات البختبرة

